\title{
IKAN PIPIH YANG POTENSIAL UNTUK IKAN HIAS
}

\author{
Sudarto \\ Balai Riset Budidaya Ikan Hias \\ Jl. Perikanan No. 13, Pancoran Mas, Depok \\ E-mail: bukembar@yahoo.com
}

\begin{abstract}
ABSTRAK
Ikan belida dikenal sebagai ikan konsumsi yang dijadikan bahan makanan seperti pempek dan kerupuk Palembang, sedangkan di Kalimantan dikenal sebagai ikan pipih. Sistematika ikan ini banyak mengalami perubahan atau perbaikan. Ikan ini termasuk famili Notopteridae yang terdiri atas 3 genus, 2 genus terdapat di Indonesia yaitu Notopterus dan Chitala. Selain itu, anak-anak ikan ini dijual sebagai ikan hias. Pengembangbiakannya di luar habitat sudah berhasil dan saat ini dalam proses peningkatan produksinya. Ikan ini hidup di sungai-sungai besar di Sumatera, Kalimantan, dan Jawa.
\end{abstract}

KATA KUNCI: ikan pipih, belida

\section{PENDAHULUAN}

Walaupun ikan pipih atau ikan belida termasuk famili Notopteridae dikenal sebagai ikan konsumsi dan diolah menjadi berbagai jenis makanan, tetapi ikan ini juga mempunyai potensi untuk dijadikan ikan hias (Roberts, 1989). Umumnya merupakan ikan yang hidup di air tawar; kadang-kadang dijumpai di air payau. Penyebarannya: Afrika dan Asia Tenggara. Ciri-cirinya adalah sirip punggung kecil seperti bulu ayam dan dasar sirip dubur panjang bertemu dengan sirip ekor yang kecil. Jari-jari sirip gabungan antara sirip dubur dan ekor berjumlah 100 atau lebih. Sirip perut jika ada ukurannya kecil dengan 3-6 jari-jari sirip. Jumlah sisik pada gurat sisi 120-180 buah. Duri-duri kecil di bagian perut 25-45 buah (Kottelat et al., 1995). Panjang maksimum $80 \mathrm{~cm}$. Ikan ukuran kecil dijual sebagai ikan hias, kebanyakan dijadikan ikan konsumsi dan diolah menjadi berbagai jenis makanan. Famili Notopteridae termasuk kelas Actinopterygii dan ordo Osteoglossiformes, terdiri atas 3 genus (Lagler et al., 1962). Hidup terutama di lingkungan perairan tawar, kadangkala dijumpai di perairan payau. Kebanyakan dari anggota famili ini mengasuh anaknya. Cara berenang ikan dewasa dari famili ini adalah gymnotiform. Dibandingkan dengan ikan lain maka golongan ikan ini bersifat tenang (kalem). Dijumpai dari $25^{\circ}$ lintang utara sampai $12^{\circ}$ lintang selatan, dan $18^{\circ}$ bujur barat hingga $119^{\circ}$ bujur timur. Etymologi nama famili ini dari bahasa Yunani, noton sama dengan belakang + , pteron sama dengan sayap, sirip.

Taksonomi famili Notopteridae adalah:

$\begin{array}{ll}\text { - Domain } & \text { : Eukaryota } \\ \text { - Kingdom } & \text { : Animalia } \\ \text { - Subkingdom } & \text { : Bilateria } \\ \text { - Infrakingdom } & \text { : Chouterostomia } \\ \text { - Phylum } & \text { : Chordata } \\ \text { - Subphylum } & \text { : Vertebrata } \\ \text { - Infraphylum } & \text { : Gnathostomata } \\ \text { - Superclass } & \text { : Osteichthyes } \\ \text { - Class } & \text { : Osteichthyes } \\ \text { - Subclass } & \text { : Actinopterygii } \\ \text { - Infraclass } & \text { : Actinopteri } \\ \text { - Order } & \text { : Osteoglossiformes } \\ \text { - Suborder } & \text { : Notopteroidei } \\ \text { - Family } & \text { : Notopteridae }\end{array}$

\section{GENUS Chitala}

Salah satu genus dari famili ini adalah genus Chitala yang terdiri atas 6 spesies yaitu C. blanci (Indochina Featherback) $C$. borneensis (Indonesian Featherback) $C$. chitala (Clown Knifefish) C. hypselonotus dan C. lopis (Giant Featherback) C. ornata (Clown Featherback). Nama ilmiah Chitala telah mengalami perbaikan dan nama yang sah atau valid adalah:

\section{Chitala lopis}

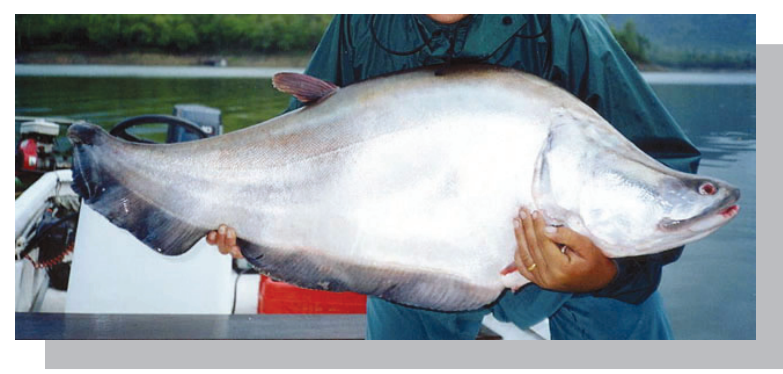


Sinonim: Notopterus borneensis, Notopterus maculosus, Notopterus hypselonotus, Notopterus lopies, Notopterus lopis

Nama Inggris/nama dagang: Indonesian Doubles Cardinalfish, Indonesian Featherback, Giant featherback.

Nama Indonesia/nama daerah: Ikan belida, ikan pipih.

Deskripsi morfologis: Panjang maksimum mencapai 150 $\mathrm{cm}$. Rahangnya bertambah panjang sepanjang hidupnya; ikan kecil (anaknya) dengan pita yang sedikit kabur pada tubuh dan sirip dubur, benih yang lebih besar dan ikan dewasa dengan tubuh terang, keseluruhannya berwarna keperakan dan menjadi perak selama hidupnya.

Habitat dan perkembangbiakannya: Ikan yang hidup di sungai dan danau di perairan demersal air tawar. Makanannya ikan, diduga mempunyai pola aktivitas crepuscular atau nocturnal yaitu mencari makan pada malam hari.

Daerah penyebaran: Asia: Kalimantan, Sumatera, dan Jawa di Indonesia, Malaysia, dan Thailand. Dijumpai di DAS Mekong.

Status pembudidayaannya/nilai ekonomi: Sebenarnya ikan belida adalah jenis ikan konsumsi yang cukup mahal harganya. Diolah menjadi berbagai jenis makanan, tetapi pada ukuran kecil (anaknya) dijual orang sebagai ikan hias. Karena penangkapan yang intensif maka saat ini populasinya cenderung menurun tajam dan sudah ada upaya pembudidayaannya di luar habitatnya dan sudah mulai ada keberhasilan.

Tingkat konservasi: Belum ada usaha konservasi.

\section{Chitala chitala}
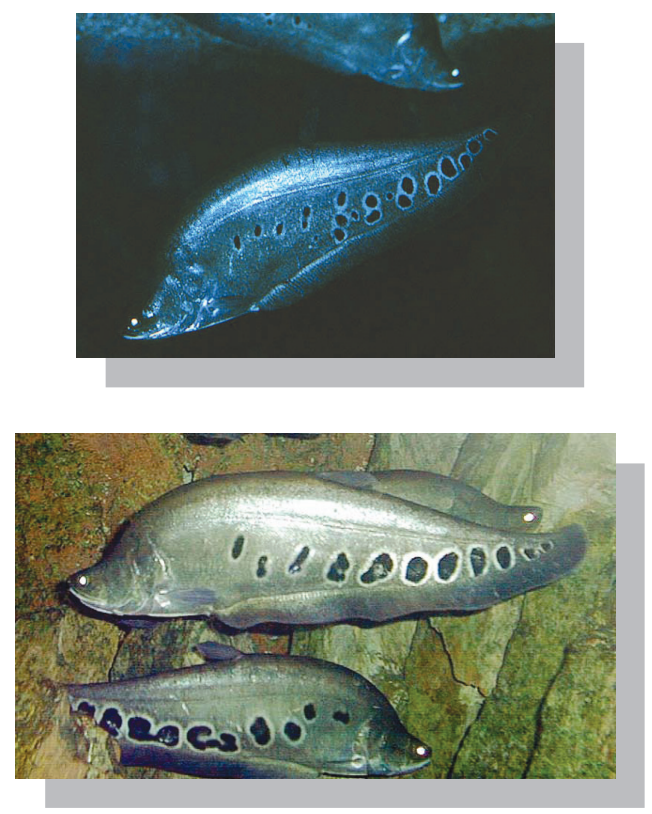

Sinonim: Chitala cliltula, Mystus chitala, Notopterus buchanani, Notopterus chilata, Notopterus chitala, Notopterus maculatus

Nama Inggris/nama dagang: Clown Knifefish, Feather Back, Knife Fish, Thousand Dollar Knife Fish.

Nama Indonesia/nama daerah: Ikan belida, lopis, belido, pipih

Deskripsi morfologi: Panjang maksimum mencapai 122 $\mathrm{cm}$, tidak mempunyai duri sirip punggung; jari-jari lunak sirip punggung 9 buah, jari-jari lunak sirip dubur 117-127 buah. Merupakan satu satunya spesies di mana ikan muda dan dewasa yang mempunyai satu seri pita berwarna emas atau perak pada bagian punggung, tetapi warna ini tidak selalu ada (Lagler et al., 1962). Berbeda dengan C. ornata yang tidak memiliki noktah bundar (ocellated) dengan C. blanci dan C. lopis yang tidak mempunyai noktah hitam pada dasar sirip dada. Anak ikan dengan 13 hingga 15 pita lebar menyilang miring yang berwarna gelap pada sisi tubuhnya. Sirip perut bersatu pada dasar sirip. Sirip dubur bersambungan dengan sirip ekor.

Habitat dan perkembangbiakannya: Perairan demersal air tawar, pH antara 6-8; dH antara 5-19 (Paysan, 1975). Hidup di sungai-sungai, perairan tawar, danau, cekungan, rawa-dalam, waduk dan kolam. Makanannya serangga air, siput, udang, dan ikan kecil. Meletakkan telur di batangbatang kayu tenggelam, dijaga oleh induknya. Telurtelurnya diaerasi oleh ikan jantan dengan mengibaskan ekornya agar terhindar dari debu halus yang terikut air; menjaga dari ikan predator seperti jenis lele; menghindari nelayan; betina tidak tampak menjaga telur.

Daerah penyebaran: Asia terdapat di DAS Sungai Indus, Gangga-Brahmaputra, dan Mahanadi di India. Laporan mengenai Chitala chitala dari Thailand dan Indo-China didasarkan pada Chitala ornata dan yang berasal dari Malaysia dan Indonesia yaitu Chitala lopis.

Status pembudidayaannya/nilai ekonomi: Sudah mulai didomestikasi dan sudah ada yang berhasil dikembangbiakkan walaupun masih bersifat pemijahan alami di luar habitatnya.

Tingkat konservasi: Belum ada usaha konservasi walaupun ikan ini sudah mengalami penurunan hasil tangkapan dari waktu ke waktu.

Genus lainnya dari famili Notopteridae yang ada di Indonesia adalah Notopterus dengan anggota yaitu: $N$. afer congensis, $N$. afer congoensis, $N$. karipat, $N$. lepus, $N$. macdonaldi, N. nonopterus, N. notopterus (Asiatic Knifefish), $N$. ocellatus salah satu di antaranya yang terdapat di Indonesia adalah (Saanin, 1952): 


\section{Notopterus notopterus}

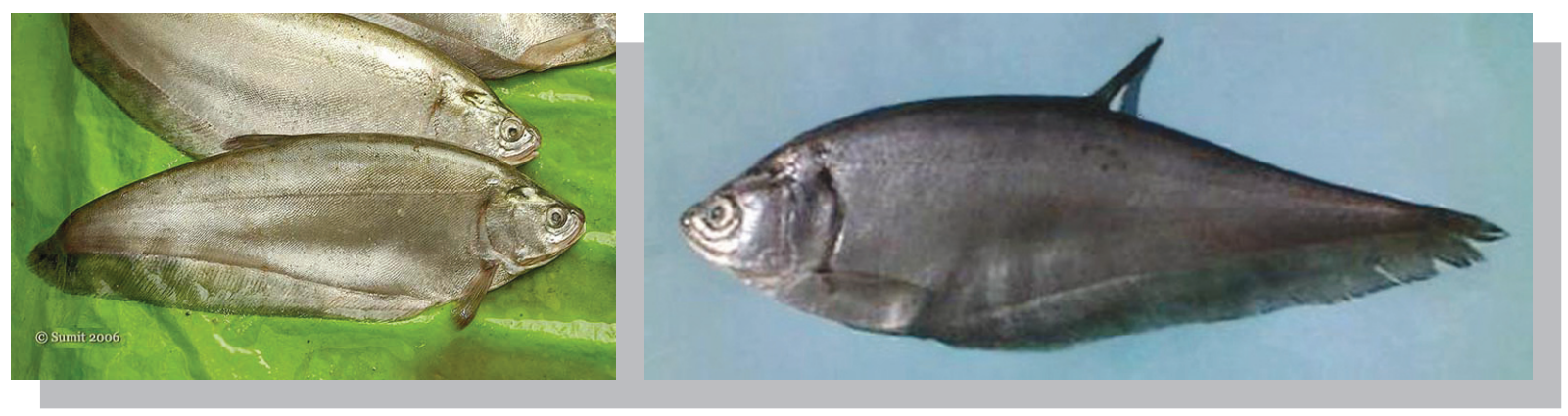

Sinonim: Clupea synura, Gymnotus notopterus, Mystus badgee, Mystus kapirat, Notopterus bontianus, Notopterus kapirat, Notopterus kopirot, Notopterus osmani, Notopterus pallasii, Notopterus primaevus

Nama Inggris/nama dagang: Bronze featherback, Asiatic Knifefish, Common Knife Fish, Feather Back, Grey Featherback.

Nama Indonesia/nama daerah: Ikan putak (Schuster \& Djajadiredja, 1952).

Deskripsi morfologi: Panjang maksimum mencapai 60 $\mathrm{cm}$. Jari-jari lunak sirip punggung 7-9 buah, jari-jari lunak sirip dubur 97-111 buah. Dapat dibedakan antara ikan dewasa berwarna coklat merata dan bentuk punggung kepala yang cembung atau agak cekung; yuwana $(<5 \mathrm{~cm}$ $\mathrm{SL}$ ) mempunyai pita warna gelap seluruh badannya; sisik di depan operculum ada 6-8 baris, badan kepala berwarna putih-perak dengan banyak titik-titik abu-abu kecil.

Habitat dan perkembangbiakannya: Demersal, potamodromous, air tawar, payau dengan $\mathrm{pH}$ antara 6,0-6,5; dH antara 3-8. Dijumpai di sungai kecil yang jernih dan memasuki perairan payau. Mendiami perairan danau yang tenang dan beraliran lemah, di rawa banjiran, kanalkanal, dan kolam. Memakan serangga, ikan, udang, dan akar muda dari tanaman air. Aktif pada temaram dan malam hari. Bergerombol dan memijah setiap tahun selama musim hujan dan migrasi kembali ke tempat asalnya pada musim kemarau. Bertelur pada rumpun kecil tanaman yang berakar di dalam air. Induk betina dengan ukuran 21-25 $\mathrm{cm}$ biasanya menghasilkan telur 1,200-3,000 butir. Ikan ini mempunyai nilai ekonomi tinggi sehingga di Sumatera dan Kalimantan dan juga di Negara Asia Selatan dan Asia Tenggara menjadi mata pencaharian nelayan dengan peralatan skala kecil. Tetapi akibat penangkapan lebih dan diversifikasi habitat ikan ini menjadi perkebunan, perumahan, dan lain-lain, maka ikan ini sudah sulit didapat. Ikan ini enak dimakan segar atau dikeringkan. Sup ikan ini baik untuk penderita campak atau cacar air.
Daerah penyebaran: Asia: Indus, Gangga-Brahmaputra, Mahanadi, Krishna, Cauvery, Irrawaddy, dan Salween; Meklong, Chao Phraya, Mekong, dan di DAS sungai-sungai di semenanjung Thailand dan Malaysia; Sumatera, Jawa, dan Kalimantan.

Status pembudidayaannya/nilai ekonomi: Belum dibudidayakan walaupun ada kecenderungan sudah menurun populasinya dari hasil tangkapan dari waktu ke waktu.

Tingkat konservasi: Belum ada usaha konservasi.

\section{KESIMPULAN}

Ikan belida atau belido atau ikan pipih merupakan jenis ikan konsumsi yang dijadikan bahan makanan seperti pempek dan kerupuk. Anak-anak ikan ini dijual sebagai ikan hias. Ikan ini termasuk Famili Notopetridae yang terdiri atas Notopterus notopterus, Chitala chitala, dan Chitala lopis. Hidup di sungai-sungai besar dan belum ada usaha konservasi walaupun populasinya di alam mengalami penurunan dari tahun ke tahun.

\section{DAFTAR ACUAN}

Kottelat, M., Whitten; A.J., Kartikasari, S.N., \& Wirjoatmodjo, S. 1995. Freshwater Fishes of Western Indonesia and Sulawesi. Periplus Edition (HK) Ltd. And Ministry of State for Population and Environtment. Rep. of Indonesia, 293 pp.

Lagler, K.F., Bardach, J.E., \& Miller, R.R. 1962. Ichthyology. John Wiley and Sons, Inc. New York, 545 pp.

Paysan, K. 1975. The country life guide to Aquarium Fishes. Country life books, 239 pp.

Roberts, T.R. 1989. The freshwater fishes of Western Borneo (Kalimantan Barat, Indonesia). California Academy of Sciences. San Francisco, 210 pp.

Saanin, H. 1952. Kunci identifikasi ikan. Van Hoeve, Bandung, $200 \mathrm{hlm}$. 
Schuster, W.H. \& Djajadiredja, R.R. 1952. Local common names of Indonesian fishes. N.V. Penerbit W. Van Hoeve. Bandung, $276 \mathrm{hlm}$. 